\title{
DIMENSIONS OF STRATEGIC MANAGEMENT IN THE CONTEXT OF MICRO AND SMALL-SIZED ENTERPRISES
}

\section{DIMENSÕES DA GESTÃO ESTRATÉGICA NO CONTEXTO DAS MICRO E PEQUENAS EMPRESAS}

\author{
Vaniele Coelho de Souza Mendes ${ }^{1}$ \\ Daniela Freitas de Oliveira ${ }^{2}$ \\ Andréia Maria Kremer ${ }^{3}$ \\ Rafael Todescato Cavalheiro ${ }^{4}$
}

\begin{abstract}
Given the economic and social importance of Micro and Small Enterprises (MSEs) and the management challenges faced by these companies, this study sought to diagnose the Strategic Management (SM) of MSEs, focusing on the dimensions of information sources, organizational behavior, competence formation, strategy formulation and inter-functionality. Data were collected through a questionnaire and analyzed using cluster analysis. In addition, Fisher's exact test was performed to verify whether the adoption of SM is associated with the profile of the manager and the company. The results reveal that MSEs have difficulties in accessing information, in encouraging team participation and centralizing decision-making. Although the personal characteristics of the manager are not associated with strategic practices, it is assumed that training in the area could contribute to the adoption of SM in the context of MSEs.
\end{abstract}

Keywords: Strategic management. MSEs. Competences. Organizational behavior.

\section{Resumo}

Dada a importância econômica e social das Micro e Pequenas Empresas (MPEs) e dos desafios de gestão enfrentados por essas empresas, este estudo buscou realizar o diagnóstico da Gestão Estratégica (GE) de MPEs, com enfoque nas dimensões fontes de informações, comportamento organizacional, formação de competências, modo de formulação de estratégias e interfuncionalidade. Os dados foram coletados por meio de questionário e analisados através da análise de clusters. Complementarmente realizou-se o Teste exato de Fisher para verificar se a

\footnotetext{
${ }^{1}$ Master's student in Agribusiness at the Federal University of Grande Dourados. Graduated in Administration from the Faculty of Education, Technology and Administration of Caarapó - FETAC, Caarapó - MS, Brazil. E-mail: vaniellecoelho@hotmail.com

${ }^{2}$ Postgraduate student in Strategic Business Management at the Faculty of Education, Technology and Administration of Caarapó (FETAC) and Bachelor of Administration (FETAC), Caarapó - MS, Brazil. E-mail: danielafreitas2097@gmail.com ${ }^{3} \mathrm{PhD}$ in Administration (UFMS). Administrator of the Federal University of Grande Dourados and Professor at the Bachelor of Public Administration at EaD/UFGD. Professor at the Faculty of Education, Technologies and Administration of Caarapó, Caarapó - MS, Brazil. E-mail: andreiakremer@hotmail.com

${ }^{4} \mathrm{PhD}$ student in Controllership and Accounting (FEA/USP-RP). Adjunct Professor at the Faculty of Education, Technology and Administration of Caarapó (FETAC) and Administrative Technician at the Federal University of Grande Dourados (UFGD), Caarapó - MS, Brazil. E-mail: rafaeltodescato@hotmail.com
} 
adoção da GE está associada com o perfil do gestor e da empresa. Os resultados revelam que as MPEs possuem dificuldades no acesso a informação, no incentivo à participação da equipe e centralizam a tomada de decisões. Apesar das características pessoais do gestor não estarem associadas às práticas estratégicas, supõe-se que uma formação na área poderia contribuir para a adoção da GE no contexto das MPEs.

Palavras-chave: Gestão estratégica. MPEs. Competências. Comportamento organizacional.

\section{Introduction}

Strategic Management (SM) in organizations has been the subject of study from several perspectives. The focus on the analysis of SM models (MILES; SNOW, 1978; MINTZBERG, 1973), in its importance (GONÇALVES et al., 2017; SAHNI, 2017), the impact on performance (CHEN; KEUNG, 2019; CHEN; MATTIODA ; DAUGHERTY, 2007) and the challenges faced in organizations (WIT, 2017) have prevailed. However, most studies still focus on the reality of large organizations, leaving small companies in the background (SANTOS; DOROW; BEUREN, 2016; UPSON; GREEN, 2017).

Small businesses represent more than 95\% of the economy in countries such as Brazil, Turkey, the United Kingdom, the Czech Republic, Germany, France, Australia, the United Kingdom and the United States (BELLAMY et al., 2019; KARADAG, 2015; LIBERMAN -YACONI; HOOPER; HUTCHINGS, 2010; SEBRAE, 2013; ŠVÁROVÁ; VRCHOTA, 2013; VERHUN; VERHUN, 2017). They are considered the backbone of many economies, as they generate jobs, income and development (CHARLES; OJERA; DAVID, 2015; FU et al., 2014; KARADAG, 2015; VERHUN; VERHUN, 2017).

In addition to their economic and social importance, Micro and Small-sized Enterprises (MSEs) have particularities that make them different from large companies. Among the main differences we can mention the scarcity of resources, not only financial or material, but also the lack of time dedicated to management, inexperience and lack of technical knowledge in the various areas of the business (ELKHOULY; MARWAN, 2016; GARRIDO-LOPEZ et al., 2018; GHOBADIAN; GALLEAR, 1996; KARADAG, 2015; MITCHELL et al., 2015; MORARU; POPA, 2018; SAHNI, 2017; UPSON; GREEN, 2017). Many of these problems could be predicted and avoided if SM was used at the stage of MSE development (LIBERMAN-YACONI; HOOPER; HUTCHINGS, 2010; SANTOS; DOROW; BEUREN, 2016; ŠVÁROVÁ; VRCHOTA, 2013).

Despite the importance and particularities of MSEs, there is a lack of studies focused on management diagnosis that consider such characteristics, since the strategy, when applied to small businesses, requires a great degree of simplification (SHARMA, 2011). In view of this, this article aims to carry out the diagnosis of SM of MSEs, focusing on dimensions that promote the integration of organizational behavior characteristics and the competence formation process. As Brazil is one of the countries benefiting from MSEs, it was decided to analyze the management of small businesses, located in a municipality in the interior of the state of Mato Grosso do Sul, in the center-west region of Brazil.

In the literature, studies were found on SMEs' SM, however, they are based on only one of the aspects addressed here or only mention the existence, nonexistence or importance of SM (BEHLING; LENZI, 2019; CHEN; KEUNG, 2019; GONÇALVES et al., 2017; HABIB; HASAN, 2019; MORARU; POPA, 2018; SOARES; TEIXEIRA; PELISSARI, 2011; UPSON; GREEN, 2017; WEBER; GENESTE; CONNELL, 2015), this being a differential of this study. To meet the proposed objective, initially the theoretical aspects that underlie the SM analysis will be discussed and, later, a diagnosis will be made through cluster analysis.

The main contribution of the study lies in testing the applicability of the combination of aspects in the organizational diagnosis, since it, is understood that the failure in one aspect can cause failures in the others. Furthermore, in the practical aspect of the MSEs, the study allows to identify the characteristics and actions to be improved in the SM of the studied MSEs. The relevance of this research becomes greater when considered in the context of a developing economy, in which MSEs play an important role in restructuring the economy after moments of economic and commercial crises.

\section{Theoretical background}


The concept of SM is usually associated with the process of analysis, decision and actions that an organization undertakes to create and sustain competitive advantages (SAHNI, 2017). This process should consider the company's development in relation to the means and forms of its activities, internal relations system and the company's position in the environment, in relation to competitors and consumers (DAUDA; AKINGBADE; AKINLABI, 2010; SOUZA; OLIVEIRA; MORAES, 2016 ; VERHUN; VERHUN, 2017).

In order to analyze the process as a whole, following the concept presented, in this study will be addressed as variables of analysis:

a) information sources (internal and external sources);

b) characteristics of organizational behavior;

c) competence formation process;

d) ways of formulating strategies; and

e) interfunctionality.

\section{a) Information sources}

The information sources provide the basic data necessary for the formulation of SM (CRUCERU, 2015; VRCHOTA et al., 2016). Information is important for supporting the decision, supporting the projection of new products, being a factor of synergy through the links and relationships between the units and, finally, for being a determining factor of behavior (LESCA; ALMEIDA, 1994). Decision support occurs due to the reduction of uncertainty, which is provided by information from internal and external sources (JOSHI; ANAND, 2018).

Internal sources are related to the analysis of resources, capacities, functional analysis, organizational structure, culture and organizational climate (NASSIF et al., 2015). Generally, the internal sources of information are chosen by the managers of small companies, since they do not have the organizational structure and processes necessary for external analysis (JOSHI; ANAND, 2018; MCGEE; SAWYERR, 2003).

External sources of information include commercial publications, direct contact with customers, suppliers and executives of other companies, feedback systems and social networks (MCGEE; SAWYERR, 2003). Customers, competitors and suppliers are the most important sources of external information, as customers bring their desires and needs, competitors bring information from the market and suppliers bring information regarding the acquisition of inputs (DRUCKER, 2001; VRCHOTA et al., 2016).

\section{b) Organizational behavior}

Organizational behavior is related to the analysis of the behavior of the groups that make up the company, mainly related to the way they think, perceive and decide on the tasks to be performed at work (BOWDITCH; BUONO, 2002; ROBBINS, 2002). In the field of strategy, strategic behavior encompasses the process of organizational adaptation to the environment, involving the choices they make over time (BEHLING; LENZI, 2019).

According to Miles and Snow (1978), many theories have studied organizational behavior, however, due to the complexity of organizations, none of them has been able to contemplate all forms of behavior. To fill this gap, Miles and Snow (1978) developed a strategic typology, in four profiles (Chart 1), which are based on the response of companies to changes in the market and the external environment. According to the authors, in general, companies always fall into one of the types proposed. 
Chart 1: Taxonomy of organizational behavior proposed by Miles and Snow (1978)

$\begin{array}{|cc|}\begin{array}{c}\text { Defender } \\ \text { Prospector }\end{array} & \begin{array}{c}\text { Organizations with product dominance, narrow market. They don't } \\ \text { look opportunities outside. } \\ \text { Organizations that constantly seek new market opportunities. They are } \\ \text { creators of change and uncertainty. } \\ \text { Onalyser }\end{array} \\ \begin{array}{l}\text { Organizations that operate on two fronts: a stable one and a changing } \\ \text { one. In the stable area they operate routinely and in the turbulent area they } \\ \text { constantly seek new ideas. }\end{array} \\ \begin{array}{l}\text { Organizations that perceive changes in their environment, but are } \\ \text { Reactor } \\ \text { unable to respond adequately, as they do not have a consistent strategy- } \\ \text { structure relationship. }\end{array}\end{array}$

Source: Miles and Snow (1978)

The great advantage of the proposed classification is the possibility of application in organizations of any size, due to the simplicity of adjusting organizational behavior to one of the categories (BEHLING; LENZI 2019). This classification was validated in the businesses of the most diverse sectors and sizes (CHARLES; OJERA; DAVID, 2015; CHEN; KEUNG, 2019; DEY; SHARMA; PANDEY, 2019; GONÇALVES et al., 2017; HABIB; HASAN, 2019; MORARU; POPA, 2018; SOLLOSY; GUIDICE; PARBOTEEAH, 2019).

\section{c) Competence formation}

The competence formation process influences the direction that the company creates for its management. Competences are conceptualized as a set of qualifications that the individual has, as well as his ability to put them into practice (ZARIFIAN, 1999). In the area of strategy, Ansoff (1990) argues that competences lead and guide the strategic behavior of organizations.

In this sense, competency-based management contributes to the company's strategic direction, in addition to allowing the identification and development of individual and organizational competencies. Organizational capacity is directed towards the management and development of knowledge, including tangible and intangible assets and individual characteristics of employees (MORARU; POPA, 2018; SOUZA; OLIVEIRA; MORAES, 2016). In this sense, the development of capacities must consider the personal growth, integrating the economic value, aimed at reaching the organizational objectives, and the social value, focused on the skills, knowledge and attitudes of the individual (FLEURY; FLEURY, 2001).

In this regard, Cruceru (2015) mentions the learning of MSEs, both individual and organizational, as an important characteristic of the process of developing the knowledge-based strategy. Ghobadian and Gallear (1996) argue that MSEs have advantages in this type of management, as it is easier for these companies to create an environment of participation and personal growth.

\section{d) Strategy formulation}

The way of formulating company strategies, proposed by Mintzberg (1973), defines organizations according to the way they make important decisions and how it connects to form strategies. The characterization of each type is described in Chart 2. 
Chart 2: Characteristics of the ways of formulating strategies

\begin{tabular}{|l|l|l|}
\hline Entrepreneurial mode & Adaptive mode & Planning mode \\
dominated by the active & - Absence of clearly defined & - The planner applies scientific \\
search for new opportunities. & objectives. Strategy making & management techniques and \\
- Power is centralized in the & between members of a & formulates long-range strategies. \\
chief executive, who defines & complex coalition, without a & - Formal planning involves looking \\
bold courses of action to be & central source of power. & existing problems. The process is \\
followed by the organization. & - Characterized by the & always systematic and structured, \\
- Strategy development is & "reactive" solution to existing & with a cost-benefit assessment. \\
characterized by dramatic & problems, rather than the & - It is characterized by the \\
leaps in the face of & search for new opportunities. & integration of decisions and \\
uncertainty. & - Incremental decision making. & strategies. \\
- Growth is the dominant & - Decisions are disconnected. & - Formal analysis can provide an \\
objective. & & understanding of the environment \\
& & \\
\hline
\end{tabular}

Source: Mintzberg (1973).

Several studies have addressed the importance and influence of how strategies are developed in organizations' performance and SM, including MSEs (ABOLFAZLI et al., 2019; KYOBE, 2008). However, it appears that the characteristics presented here are influenced and influence the other variables studied, such as the sources of information, competence development and interfunctionality.

\section{e) Interfunctionality}

Interfunctionality refers to an integration between the various parts of an organization, reducing departmental boundaries, allowing analysis through a strategic level of the entire organization (PAGELL, 2004; VARGO; LUSCH, 2004). The integrated coordination of different functional departments has been cited as a source of competitive advantage for organizations (BERGENHOLTZ; BJERREGAARD, 2014; YANG; JIANG; ZHAO, 2019).

Interfunctional coordination allows transforming knowledge into competencies, which directly interfere with the organization's performance (YANG; JIANG; ZHAO, 2019). When considering this aspect, MSEs have a natural tendency towards multifunctional training, because they have fewer layers of management and personnel (GHOBADIAN; GALLEAR, 1996).

The relevance and applicability of each of the dimensions addressed in the SM analysis of organizations is verified. This study seeks to apply all dimensions in the diagnosis of the same MSEs, allowing a more comprehensive analysis, including the influence relationships between them.

\section{Methodology}

In order to carry out SM's diagnosis of MSEs, focusing on dimensions that promote the integration of organizational behavior characteristics and the competence formation process, 30 MSEs were selected from the sectors of industry, commerce and services located, in the Mato Grosso do Sul state. The selection of enterprises was based on compliance with the basic premises that characterize an MSE and, mainly, the availability of the manager to participate in the research. For the selection, the non-probabilistic sample for convenience was used. In this study, we chose to use the SEBRAE MSE classification, by number of employees, since it is the standard approach in the management literature (LIBERMAN-YACONI; HOOPER; HUTCHINGS, 2010).

As a data collection instrument, a questionnaire consisting of 10 open and closed questions on the profile of respondents and 48 closed questions related to the organizational diagnosis was adopted, including characteristics related to the five dimensions addressed in this study. In the questions about organizational diagnosis, the five-point Likert scale was used, 5 forever, 4 frequently, 3 sometimes, 2 rarely and 1 never.

The data obtained were analyzed by means of cluster analysis, which presents itself as a statistical technique that makes it possible to group objects according to their characteristics, forming homogeneous groups or conglomerates (HAIR JR. et al., 2009). For cluster analysis, Minitab multivariate analysis software, version 12.1 , was used. We opted to use the complete linkage hierarchical grouping method, also known as the most distant neighbor method, which defines the 
similarity between clusters with the greatest distance between observations in each cluster. For the classification of clusters, it was decided to analyze the five dimensions proposed in isolation.

After the analysis of clusters, the association analysis was carried out, using Fisher's Exact Test, to investigate whether there is an association between the groups obtained and the profile information of the managers. Experience, education and technical support and grouping were tested. The level of significance was set at $5 \%$ and all analyzes were performed with the aid of the Stata software, version 13.0.

\section{Results and discussions}

As mentioned in the methodology section, profile information of respondents was initially identified. Among the respondents, it is highlighted that, around $47 \%$ are female and $53 \%$ male, most respondents (80\%) are over 30 years old and 37\% have between 6 and 10 years of experience in management, $40 \%$ over 10 years and only $23 \%$ have less than 5 years of experience.

Regarding education, most managers $(60 \%)$ have completed or incomplete higher education, 2 do not have complete elementary school, 4 have elementary school and 6 high school. The $40 \%$ with high or elementary school represent a significant group of managers who did not obtain specific training in management.

There is a predominance of family businesses, as 16 of the 30 companies rely on family work. This result is significant, since 23 companies have up to 10 employees, among them, some composed only of family members. Of the rest, four companies have between 11 and 20 employees and three have between 30 and 50 employees. These companies are divided into different sectors of activity, covering industry (1), commerce (21) and services (8).

After identifying the profile of the participants, the following factors were analyzed: source of information, formation of competencies, organizational behavior, formulating strategies and interfunctionality. Due to the characteristics of each factor, it was initially chosen to carry out the analysis of each dimension of the GE in isolation, with the purpose of giving greater reliability to the results. From the data obtained in the questions related to each factor, the analysis of clusters allowed the creation of a dendogram, which shows the groups of companies, with similar answers.

The first dimension analyzed is the sources of information, which allow the assessment of the company's environment. The results are shown in Figure 1.

Figure 1: Dendrogram of the information source dimension

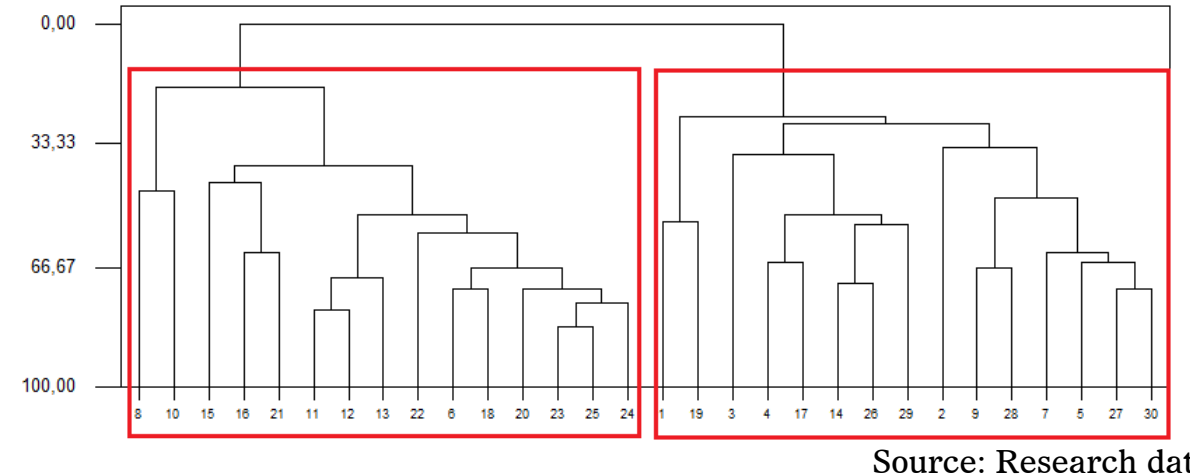

Source: Research data (Minitab 12.1)

According to the characteristics of internal and external sources, respondents are classified into two groups. The companies in the first group have as common characteristics the fact that they often use only the opinion of the manager to change the company's policies and frequently update their internal information about customers and the market. The second group, on the other hand, is represented by companies that only use the opinion of the manager to change the company's operating policies and rarely or never update their internal information.

As mentioned above, internal sources refer to the analysis of resources, capabilities, functional analysis, organizational structure, culture and organizational climate (NASSIF et al., 2015). In relation to this information, it appears that half of the companies analyzed (group 2) do not pay due attention to internal sources of information. Such a result can be harmful to the success of the organization, since the opinion and participation of employees as a source of information can be 
decisive for improving the company's performance and reducing uncertainties (ENTRIALGO; FERNÁNDEZ; VÁZQUEZ, 2000; LESCA; ALMEIDA , 1994; SAHNI, 2017; SEQUEIRA et al., 2018).

This scenario is even worse as the external information, which refers to customers, competitors and suppliers (DRUCKER, 2001; VRCHOTA et al., 2016). Regarding access and response time to external information, both groups have the same characteristic, rarely or sometimes the company is able to obtain important external information and that the time between the search for information and the commitment to action occurs between 1 and 6 months. For Drucker (2001), the greatest threats and opportunities for companies arise from the external environment, so it is necessary to obtain this information quickly and conveniently, ensuring a competitive advantage for the company.

The results obtained here corroborate with Joshi and Anand (2018), that in general, MSEs give priority to obtaining internal information, leaving external information in the background. Such a situation can be justified by the proposal of Fu et al. (2014), that the majority of MSEs have little understanding and less structure, of the application of information technology, which makes the integration of their suppliers and customers difficult.

The lack of access to information can cause the companies surveyed to have difficulties in taking advantage of market opportunities, as well as difficulties in overcoming their failures, leading to a process of obsolescence. Furthermore, these limitations in accessing information directly impact the other factors analyzed, as they serve as a basis for the creation of strategies, for the formation of competences, and have an impact on organizational behavior and interfunctionality.

After verifying the access to information dimension, the next aspect analyzed is organizational behavior, based on the typology of Miles and Snow (1978). The Figure below represents the groups that identify themselves, according to the responses.

Figure 2: Dendogram of organizational behavior

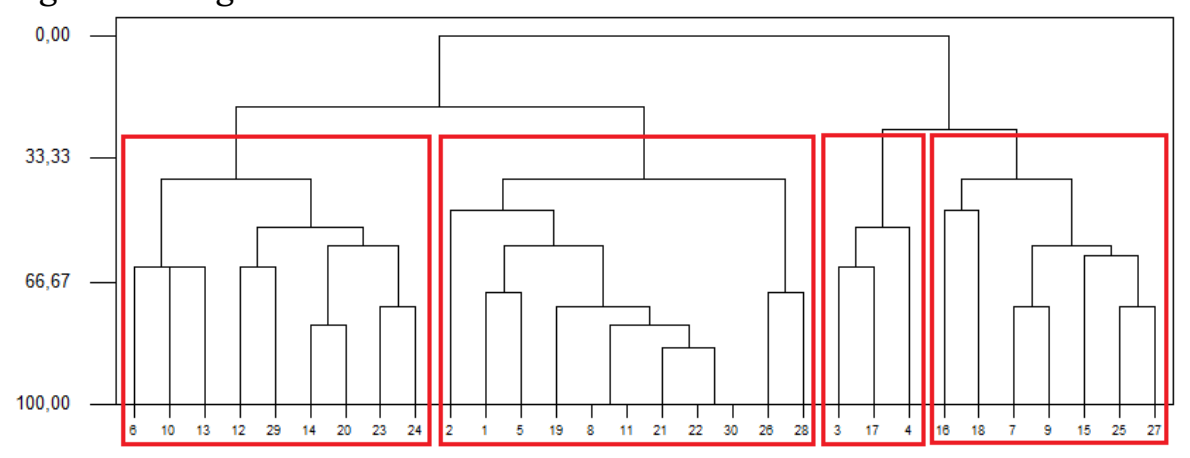

Source: Research data (Minitab 12.1)

According to figure 2, in this characteristic, respondents were classified into four groups. The first group has as main characteristics the manager's frequent knowledge about opportunities, which can be exploited in the market, they know their main competitors and the threats that exist in the market, they frequently seek new opportunities and are flexible in the division of labor. However, they have limited knowledge on how to exploit the company's internal resources that lead to a competitive advantage and have limited flexibility in the organizational structure.

In the classification of Miles and Snow (1978), this first group fits in the prospector mode, because companies with these characteristics are precursors of innovation and for that, they need to identify new opportunities. The results are similar to those obtained by Gonçalves et al. (2017) in MSEs in the Londrina (PR) city, and by Behling and Lenzi (2019) in the Santa Catarina state, where most of the companies analyzed fall into the prospector group. This is important, as the prospector type is considered to have the greatest growth potential (WEBER; GENESTE; CONNELL, 2015), in addition to being identified as the type with the highest profitability (CHEN; KEUNG, 2019).

The second group presented as common characteristics, the fact that the manager often knows the opportunities, the threats and his competitors, only sometimes does the manager know how to exploit his internal resources and look for new opportunities, the structure of the company and the division of the work are inflexible. In the classification of Miles and Snow (1978), it is a defender group, since the company has market dominance and focuses on maintaining a stable line of products and services. Although companies are aware of market opportunities and threats, managers generally do not exploit their internal resources and do not seek new opportunities. 
It was found that most of the companies analyzed fall into the defender type. Habib and Hassan (2019) mention that defenders tend to be associated with less irregularities in financial reporting, less weakness in internal control, greater stability and predictability of demands and products and, consequently, more accurate investments. In this same sense, Dey, Sharma and Pandey (2019) state that defensive organizations have advantages in becoming producers with lowcost dominance in the market. However, this type is only interesting for the types of businesses that require low cost strategies and stable market, due to the difficulty in finding new opportunities.

The third group, with only 3 companies, is characterized by managers who rarely know the market opportunities, their competitors and their threats, rarely know how to exploit the company's internal resources, have a division of labor and flexible organizational structure in only a few cases, in addition to rarely seek new market opportunities. According to Miles and Snow (1978), this group is composed of reactive companies, since the company does not perceive changes and opportunities in the market, being unable to react promptly to them. Such a situation can be determined by the lack of strategic management planning and, in these cases, the change due to opportunities and organizational flexibility only occurs as a last resort. According to Gonçalves et al. (2017), the typical approach of these establishments is to wait and see, and respond only when pressed.

Finally, the fourth group is characterized by managers who know little about the opportunities and threats of the market and rarely seek new market opportunities and make the organizational structure more flexible. In addition, the manager rarely knows the performance of his competitors, and rarely exploits the company's internal resources that lead to a competitive advantage. This group has reactive organizational behavior characteristics, however, they have difficulties regarding the reaction to the market, that is, although they may eventually see market opportunities and threats, they are unable to react because they do not have organizational flexibility and rarely exploit resources. Despite these being the types of organization with the lowest number in the studies (BEHLING; LENZI, 2019; SOARES; TEIXEIRA; PELISSARI, 2011), due to the fact that the reactors have low survival rates in competitive markets (MILES; SNOW, 1978), there is a significant number here (10 companies out of 30$)$, that is, they are companies that need to make changes urgently.

The classification proposed by Miles and Snow (1978) does not establish a right or wrong type, however, depending on the field of activity, the company adopting the defensive type can have negative consequences due to negligence in the search for opportunities, such as the loss of promising markets or the obsolescence of its products, services and processes. As mentioned earlier, this type is only suitable for types of businesses that require low-cost, stable market strategies. Regarding the reactive type, the negative consequences are even greater, as they are unable to react to changes in the market and tend to go bankrupt over time.

The next dimension of Strategic Management analyzed is the formation of competences, presented in the figure below. As mentioned above, competency training is related to the identification and development of individual and organizational competencies. Therefore, the development of capabilities must consider personal growth, integrating economic value and social value, which is focused on the individual's skills, knowledge and attitudes (FLEURY; FLEURY, 2001).

Figure 3: Dendogram of competence formation

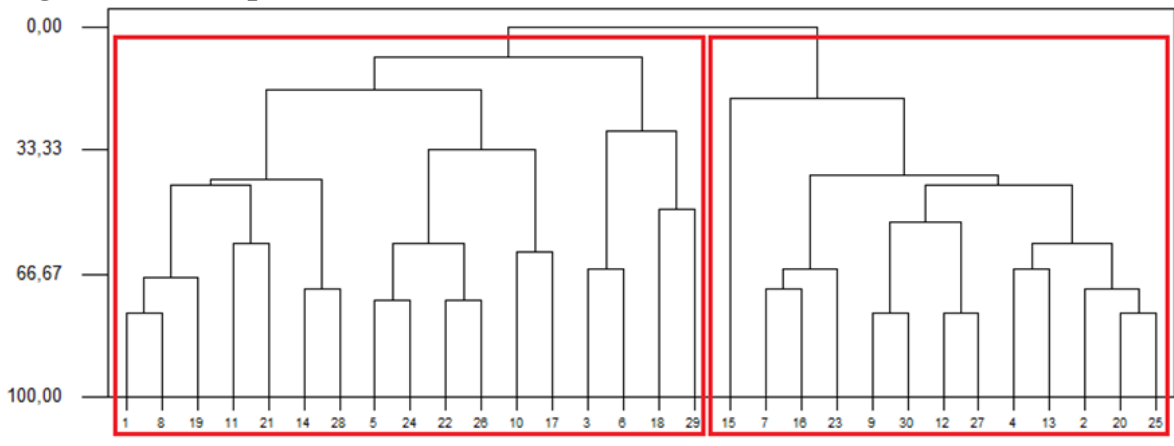

Source: Research data (Minitab 12.1)

With regard to competence formation, enterprises are divided into two groups, with similar amounts. The first group, containing 17 companies, has companies with little employee participation 
in the company's strategic decisions, in the definition of action plans and changes. In addition, employees receive few specific courses or training to perform their duties, resulting in a framework where employees sometimes lack specific knowledge to carry out their work. In this group, companies show a partial concern with the formation of social competence, given the limited incentive for employee participation and the lack of training. Such a situation can be seen as detrimental to SM, since the strategic training of the team is related to better performance levels (DAUDA; AKINGBADE; AKINLABI, 2010; PATON; WAGNER; MACINTOSH, 2012; YANG; JIANG; ZHAO, 2019).

The second group has even worse characteristics with regard to participation, as employees never participate strategically in decision making and in the preparation of action plans. In addition, managers evaluate that, in only a few situations, employees have specific knowledge for the development of their work, but that the company never offers training to employees. This group presents an even more negative result than the previous one, because in this case participation is never encouraged.

The results presented by the two groups are contrary to those obtained by Ghobadian and Gallear (1996), that small companies have advantages in the creation of social competence. Although several studies argue that one of the ways in which MSEs create sustainable competitive advantage is by leveraging their intellectual capital (CRUCERU, 2015; SAHNI, 2017; SEQUEIRA et al., 2018), it appears that this strategy is not adopted by companies studied.

By neglecting the skills training process, these companies can lose out in the use of talents and capabilities, in addition to creating a hostile and unsatisfactory environment for employees, who do not find the possibility of personal growth in the company. As a result, there is low organizational involvement, difficulties in strategic alignment, organizational climate issues, dissatisfaction and high turnover.

The way organizations formulate their strategies is also considered a determining factor for obtaining competitive advantages. The analysis of this aspect, based on the classifications proposed by Mintzberg (1973), resulted in 4 groups, as shown in the figure below.

Figure 4: Dendrogram of the ways of formulating strategies

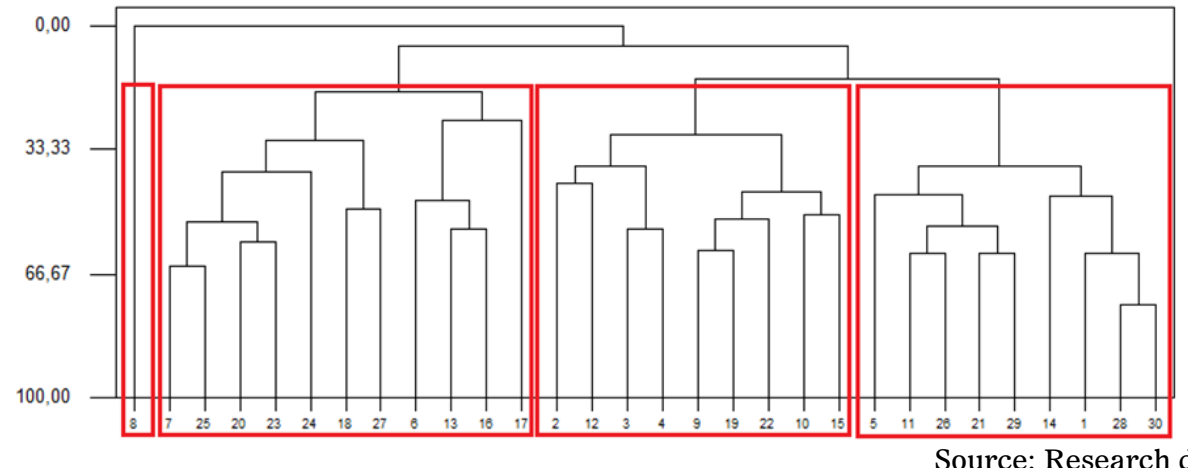

Source: Research data (Minitab 12.1)

As shown in the figure, a single company has different characteristics from the others. The manager of this company evaluated that sometimes the company carries out its strategic planning and analyzes more than two alternatives for action, often develops alliances with suppliers for the development of new products, services or technologies, but only sometimes does it develop this alliance with the customers. The manager also assesses that the company frequently seeks new products, services and technologies and that there has been an increase in sales in recent years. The company recognizes that there are new competitors entering the market segment, that customers order new products, and that recently launched products compromise their sales, but that the company often quickly adopts the new technologies that emerge, as well as quickly rearranging its resources when there are threats to your sales.

According to the definition of Mintzberg (1973), this company fits into the entrepreneurial mode, because its strategies are based on the search for new opportunities, which can result in risky or intuitive decision-making and in the realization of alliances in order to remain in the market. In addition, power is centralized in the hands of the chief executive, who defines the vision to be followed by the organization. The results obtained are in line with the characteristics of the managers who adopt the entrepreneurial mode in the MSEs in the information technology area (KYOBE, 2008). 
The remaining respondents were grouped into 3 groups with similar amounts between them. The second group has as a standard the fact that sometimes the company carries out its strategic planning, seeks new services, technologies or processes, and rarely seeks alliances with suppliers for this purpose. These behaviors result in responses that there has been neither an increase nor a drop in sales in the last three years. Managers mention that they know the market and its competitors, and the threats they represent, customers hardly ask for new products, but that the company often quickly adopts new technologies that arise and reorganize its internal resources when there is a threat from competitors .

In the classification by Mintzberg (1973), this cluster fits into the adaptive mode, as they do not carry out planning, they do not have well-defined objectives and their strategy formulation process is characterized by reacting to the problems that arise. This group focuses more on problem solving than on looking for new opportunities.

The third group indicated that the company rarely carries out its strategic planning, and when it does, it does not analyze more than two alternatives for action. It rarely develops alliances with suppliers, but in some cases, it seeks partnerships with customers for new products or technologies. The managers of this group estimate that $50 \%$ of the company's sales are related to new products or services launched in the last 2 years, and that new competitors are entering the market and are able to commercialize the main products of this company, threatening sales. New customers sometimes request new products, the company in some cases adopts the new technologies that emerge and which sometimes manages to reorganize its internal resources to fight competitors, but despite this, it has had a drop in sales in recent years. Like the previous one, this group also has the characteristics of the adaptive mode, due to the complex environment and the company's inclination to resolve conflicts instead of looking for new opportunities.

The fourth group is represented by companies that assess that they always carry out strategic planning and, when they do, they analyze more than two action options. However, managers indicated that they never develop alliances with suppliers and only in some cases do they create alliances with customers. Comparing with their competitors, respondents consider that their activities have improved and that they are better than their competitors and that they are not threatened by new competitors or products.

In the area of strategic planning, this group fits into the planning mode in the classification of Mintzberg (1973), when they answer that they always do their strategic planning, analyzing alternatives that will provide competitive advantage. However, in other matters, this group also fits in the adaptive mode, as the company does not seek new opportunities in the market, does not form new partnerships in order to develop and offer new products.

In general, it appears that the clusters formed in this dimension showed that their management lacks strategic planning and knowledge about the market, opportunities and threats. As mentioned in the previous dimensions, by neglecting this type of knowledge, the companies studied have difficulties in generating competitive advantage, in preparing a reliable and complete strategic planning, in addition to being surprised by market changes.

The last dimension of strategic management analyzed is interfunctionality, represented by the integration of the various parts of the organization (PAGELL, 2004; VARGO; LUSCH, 2004), which generates a greater flow of information and resources, being a source of competitive advantage. In the figure below, this characteristic divided the respondents into 3 groups.

Figure 5: Interfunctionality dendrogram

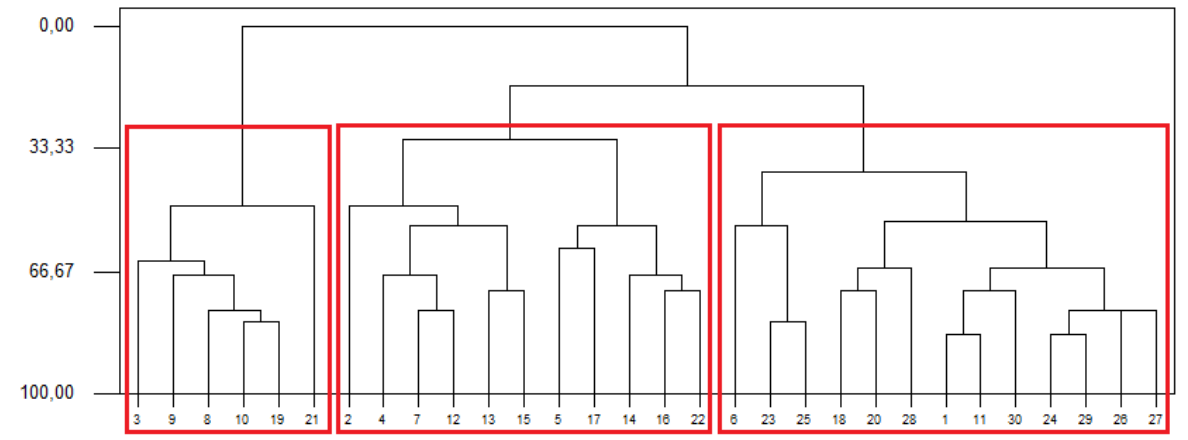

Source: Research data (Minitab 12.1) 
The first group is represented by companies in which employees rarely participate in strategic product and procedure decisions, budgetary issues or strategic decisions related to changes in the growth strategy. The company also rarely encourages employees to become familiar with all of the company's existing roles, resulting in rare suggestions for improvement in the activities of other company functions. It is evident in this group that interfunctionality is not encouraged in companies, generating functional segmentation. The second group has similar results in terms of participation in decisions, but there is progress in terms of knowing and participating in improvement discussions in other sectors of the company.

The third group has a greater participation of employees in decisions, however, there is a restriction in cases of budgetary decisions and strategic decisions for the company's growth. In addition, employees know and perform more than one function and make suggestions for improvements. It appears that the companies in the sample have very low inter-functionality, contrary to the proposition of Pagell (2004), that it is intuitively possible to say that smaller companies have more integration between their functions.

As a result of this type of behavior, it is possible to mention the lack of knowledge of the processes as a whole, the creation of an environment with a negative organizational climate, low satisfaction and high turnover, low use of internal skills, as well as loss of opportunity for improvement.

The groups are similar in relation to the employee's little participation in strategic decision making and in financial matters of companies, explaining that the internal competences in this case are not reinforced. The results corroborate with Senge (1990), that most organizations are focused on the control of the individual, demanding more obedience than their creative capacity and this reality makes organizational learning an arduous and often conflicting task. In this sense, several authors argue that companies should develop shared visions, group learning and systemic thinking (CARVALHO et al., 2016; CHEN; MATTIODA; DAUGHERTY, 2007; KUCIAPSKI, 2019; YANG; JIANG; ZHAO, 2019).

In general, it appears that the studied companies adopt positions that are not very favorable to SM limiting the development of competitive advantages, with few entrepreneurs who differentiate themselves. Several studies have identified that personal characteristics of MSE owner-managers, such as experience, social relationships, level of information and ethical values, strongly affect strategic decision-making processes in MSEs (KALKHOURAN et al., 2015; LIBERMAN-YACONI; HOOPER; HUTCHINGS, 2010).

In this sense, after analyzing the dimensions adopted in the companies, Fisher's exact test was carried out to identify whether the profile of the manager and the company are associated with the groups in which the companies fit.

It was found that the variables gender, age, education and previous experience of managers are not associated, in the analyzed companies, with the dimensions of the SM. Regarding the profile of the companies, the sector in which the company operates is only related to organizational behavior (p-value 0.053) and the degree of interfunctionality (p-value 0.019). The association of the type of organizational behavior with the sector was already expected, since in some sectors of the economy, with tougher or more dynamic competition, certain types of behavior do not allow the company to survive, such as reactive, for example. In addition, some types of behavior are more suitable for more stable sectors.

In addition to these, the number of employees was significantly associated with the way of formulating strategies (p-value 0.027). Considering that the number of employees is the determining factor in the classification of the size of the companies, there is a relationship between the size of the company and the way of formulating strategies of the manager. This result shows that the strategies change according to the company's growth. The other variables of the company profile were not related to the dimensions of SM, although several studies defend the importance of technical support and experience in the activity.

\section{Final considerations}

The objective of this study was to carry out the diagnosis of SM of MSEs, focusing on dimensions that promote the integration of organizational behavior characteristics and the process of formation of MSEs' competence. Based on the results, it was found that the MSEs analyzed have difficulties in accessing information, in encouraging team participation and centralizing decisionmaking. 
Throughout the study, the importance of organizational knowledge in SM was verified, since information, the development of internal competences and the way of formulating strategies, in an interfunctional organization, favor SM in MSEs. In this sense, access to information is one of the main weaknesses identified, directly impacting other factors. When analyzing the companies that make up each group, identified in the analysis of clusters, it appears that companies that do not have access to internal and external information tend to adopt a reactive or defensive stance, as they do not have prior information for an environmental analysis and determining strategies. The same occurs with the way of formulating strategies, where only those who have access to information are classified as entrepreneurial. The adaptive ones, divided into two groups, contain in the first group companies that have access to internal information, while in the second group, those with difficulties to react, are companies with no access to information. That is, the lack of information not only prevents the anticipation of situations, but also impairs the reaction.

As for the classifications of the types of organizational behavior and ways of formulating strategies, it is important to mention that there is no right way and no wrong way. The classifications enable the analysis of the type of strategy adopted by the companies, with the purpose of identifying possibilities for improvements in their internal processes, their environmental analysis and their strategic planning. However, it appears that some characteristics are not interesting for the maintenance of companies in the market, such as the case of reactive companies in a competitive market. In addition, it is necessary to analyze the characteristics of the business, since the defensive strategy can be considered favorable in stable environments, where low cost is considered a competitive advantage, or unfavorable in environments that require rapid innovations.

In addition to the lack of information, limiting employee participation in the definition of strategies and changes is a major flaw. Such failure is portrayed in the lack of access to internal information, in the lack of creation of economic and social value for the company and in the satisfaction of employees. It is evident that there is resistance on the part of managers when it comes to involving employees in financial and budgetary decisions, underestimating the individual competence and information brought by them, which would assist in the development of more realistic and efficient plans and actions for the reality of the business. However, centralization is assumed to be a problem for most MSEs.

Although many studies associate the centralizing behaviors and management difficulties of MSEs with profile variables, in this study this reality was not observed, since differences in education, experience and access to technical support were not associated with the dimensions of SM. Although the personal characteristics of the manager are not associated with strategic practices, it is assumed that training in the area could contribute to the adoption of SM in the context of MSEs. This result cannot be generalized for all cases, but it demonstrates a gap that can be investigated in future studies.

In general, MSEs have a need to create instruments for participation in the definition of organizational strategies, as well as mechanisms for accessing internal information and market information, in order to create a proactive stance. However, the need for professionalization of the MSEs is evident, with the inclusion of strategic management as a practice, with the aim of expanding access to markets. The results presented here can serve as a basis for technical advisory and support bodies for MSEs to carry out training and awareness actions for managers, as this is the first step towards improving participation, developing social and economic competence, access to internal information and strategy development.

The study's limitations include the sample size and the possible bias in the managers' response. It is recommended that future studies be carried out with a larger number of companies and that consider other analysis variables. Given the economic and social importance of MSEs, studies that focus on understanding their characteristics and the degree of maturity of strategic management, contribute to the development of these companies and the country, since, if MSEs are successful, society will also will have.

\section{References}

ABOLFAZLI, S. A. et al. Strategy-making process and firm performance in Iranian pharmaceutical industry. Iranian Journal of Pharmaceutical Research, v. 18, n. 1, p. 531-545, 2019.

ANSOFF, I. H. A Nova Estratégia Empresarial. São Paulo-SP: Atlas, 1990. 
BEHLING, G.; LENZI, F. C. Entrepreneurial Competencies and Strategic Behavior : a Study of Micro Entrepreneurs in an Emerging Country. Brazilian Business Review, v. 16, n. 3, p. 255-272, 2019.

BELLAMY, L. C. et al. The use of strategy tools and frameworks by SMEs in the strategy formation process. International Journal of Organizational Analysis, v. 27, n. 2, p. 337-367, 2019.

BERGENHOLTZ, C.; BJERREGAARD, T. How institutional conditions impact university-industry search strategies and networks. TECHNOLOGY ANALYSIS \& STRATEGIC MANAGEMENT, v. 26, n. 3, p. 253-266, mar. 2014.

BOWDITCH, J. L.; BUONO, A. F. Elementos do comportamento organizacional. São Paulo: Pioneira Thomson Learning, 2002.

CARVALHO, G. D. G. C. et al. O papel da cooperação para a inovação em micro e pequenas empresas do estado do Paraná. Revista Brasileira de Gestão e Desenvolvimento Regional, v. 12, n. 3, p. 419442, 2016.

CHARLES, N. A.; OJERA, P. B.; DAVID, O. Factors influencing choice of strategic management modes of small enterprises. Journal of Innovation and Entrepreneurship, v. 4, n. 4, p. 1-22, 2015.

CHEN, G.; KEUNG, E. C. The impact of business strategy on insider trading profitability. PacificBasin Finance Journal, v. 55, p. 270-282, 2019.

CHEN, H.; MATTIODA, D. D.; DAUGHERTY, P. J. Firm-wide integration and firm performance. The International Journal of Logistics Management, v. 18, n. 1, p. 5-21, 2007.

CRUCERU, A. SMEs and strategic management based on knowledge. Romanian Economic and Business Review, v. 10, n. 2, p. 147-154, 2015.

DAUDA, Y. A.; AKINGBADE, W. A.; AKINLABI, H. B. Strategic Management Practice and Corporate Performance of Selected Small Business Enterprises in Lagos Metropolis. International Journal of Business and Management, v. 5, n. 11, p. 97-105, 2010.

DEY, S.; SHARMA, R. R. K.; PANDEY, B. K. Relationship of Manufacturing Flexibility with Organizational Strategy. Global Journal of Flexible Systems Management, v. 20, n. 3, p. 237-256, 2019.

DRUCKER, P. 0 melhor de Peter Drucker: A Administração. São Paulo: Nobel, 2001.

ELKHOULY, S.; MARWAN, R. Defining the Organizational Culture that Drives Strategic Innovation in Micro, Small and Medium Enterprises in Egypt. Competition Forum, v. 14, n. 2, p. 38-47, 2016.

ENTRIALGO, M.; FERNÁNDEZ, E.; VÁZQUEZ, C. J. Linking entrepreneurship and strategic management: Evidence from Spanish SMEs. Technovation, v. 20, n. 8, p. 427-436, 2000.

FLEURY, M. T. L.; FLEURY, A. Construindo o Conceito de Competência. Revista de Administração Contemporânea, v. Ed. especi, p. 183-196, 2001.

FU, H.-P. et al. The critical success factors affecting the adoption of inter-organization systems by SMEs. Journal of Business \& Industrial Marketing, v. 29, n. 5, p. 400-416, 2014.

GARRIDO-LOPEZ, M. et al. Project-based strategic management education : A client perspective on key challenges. Journal of Small Business Strategy, v. 28, n. 2, p. 68-79, 2018.

GHOBADIAN, A.; GALLEAR, D. Total quality management in SMEs. The International Journal of Management Science, v. 24, n. 1, p. 83-106, 1996. 
GONÇALVES, G. V. et al. Configurações Estratégicas em MPES: Uma análise da atuação de mulheres empreendedoras do setor de serviços de Londrina - PR. Revista de Administração da UFSM, v. 5, n. 4, p. 652-667, 2017.

HABIB, A.; HASAN, M. M. Business Strategy and Labor Investment Efficiency. International Review of Finance, p. 1-39, 2019.

HAIR JR., J. F. et al. Análise multivariada de dados. 6. ed. Porto Alegre: Bookman, 2009.

JOSHI, M.; ANAND, V. Small business owners' external information-seeking behaviors : The role of perceived uncertainty and organizational identity complexity. Journal of Small Business Strategy, v. 28 , n. 3 , p. $48-68,2018$.

KARADAG, H. Financial Management Challenges In Small And Medium-Sized Enterprises: A Strategic Management Approach. EMAJ: Emerging Markets Journal, v. 5, n. 1, p. 26-40, 2015.

KUCIAPSKI, M. How the Type of Job Position Influences Technology Acceptance: A Study of Employees' Intention to Use Mobile Technologies for Knowledge Transfer. IEEE Access, v. 7, p. 177397-177413, 2019.

KYOBE, M. The influence of strategy-making types on IT alignment in SMEs. Journal of Systems and Information Technology, v. 10, n. 1, p. 22-38, 2008.

LESCA, H.; ALMEIDA, F. C. Administração estratégica da informação. Revista de Administração, v. 29, n. 3, p. 66-75, 1994.

LIBERMAN-YACONI, L.; HOOPER, T.; HUTCHINGS, K. Toward a Model of Understanding Strategic Australian Information Technology Sector. Journal of Small Business Management, v. 48, n. 1, p. 70-95, 2010.

MCGEE, J. E.; SAWYERR, O. O. Uncertainty and Information Search Activities: A Study of OwnerManagers of Small High-Technology Manufacturing Firms. Journal of Small Business Management, v. 41, n. 4 , p. $385-401,2003$.

MILES, R. E.; SNOW, C. C. Organizational strategy, structure and process. New York: McGrawHill, 1978.

MINTZBERG, H. Strategy-Making in Three Modes. California Management Review, v. 16, n. 2, p. 44-53, 1973.

MITCHELL, R. et al. A framework for SME retail branding. Journal of Marketing Management, v. 31, n. 17-18, p. 1818-1850, 2015.

MORARU, G. M.; POPA, D. Strategic management problems in Romanian small and medium-sized enterprises. Annual Session of Scientific Papers IMT ORADEA 2018. Anais...Oradea, Romania: MATEC Web of Conferences, 2018

NASSIF, V. M. J. et al. E o que dizem os empreendedores sobre a criação, sobrevivência e desenvolvimento de suas empresas? Um estudo exploratório. Revista Brasileira de Gestão e Desenvolvimento Regional, v. 11, n. 2, p. 216-245, 2015.

PAGELL, M. Understanding the factors that enable and inhibit the integration of operations, purchasing and logistics. Journal of Operations Management, v. 22, n. 5, p. 459-487, 2004.

PATON, R. A.; WAGNER, R.; MACINTOSH, R. Engineering education and performance: The German machinery and equipment sector. International Journal of Operations and Production Management, v. 32, n. 7, p. 796-828, 2012. 
ROBBINS, S. P. Comportamento organizacional. São Paulo: Prentice Hall, 2002.

SAHNI, J. Is Strategic Management Practice Important for Small Business Enterprises ? Evidence from Saudi Arabia. (K. S. Soliman, Ed.)Education Excellence and Innovation Management through Vision 2020. Anais...Vienna, Austria: International Business Information Management Association (IBIMA), 2017

SANTOS, V.; DOROW, D. R.; BEUREN, I. M. Práticas gerenciais de micro e pequenas empresas. Revista Ambiente Contábil, v. 8, n. 1, p. 153-186, 2016.

SEBRAE. Anuário do trabalho na micro e pequena empresa: 2013.: 6.ed. Brasilia-DF.

SEQUEIRA, J. M. et al. Making the case for diversity as a strategic business tool in small firm survival and success. Journal of Small Business Strategy, v. 28, n. 3, p. 31-47, 2018.

SHARMA, G. Do SMEs need to strategize? Business Strategy Series, v. 12, n. 4, p. 186-194, 2011.

SOARES, M. L.; TEIXEIRA, O. R. P.; PELISSARI, A. S. Uma Aplicação Da Tipologia De Miles E Snow No Setor Hoteleiro De Florianóplis , Sc. Revista Administração UFSM, v. 4, p. 251-267, 2011.

SOLLOSY, M.; GUIDICE, R.; PARBOTEEAH, K. P. Miles and Snow's strategic typology redux through the lens of ambidexterity. International Journal of Organizational Analysis, v. 27, n. 4, p. 925-946, 2019.

SOUZA, V. B. R.; OLIVEIRA, E. A. DE A. Q.; MORAES, M. B. Gestão estratégica em pequenas empresas de base tecnológica. Revista Brasileira de Gestão e Desenvolvimento Regional, v. 12, n. 3, p. 459-491, 2016.

ŠVÁROVÁ, M.; VRCHOTA, J. Strategic Management in Micro, Small and Medium-Sized Businneses in relation to financial success of the enterprise. Acta Universitatis Agriculturae et Silviculturae Mendelianae Brunensis, v. LXI, n. 7, p. 2859-2866, 2013.

UPSON, J. W.; GREEN, K. M. Dragons, Goliaths, and Cowboys: A view of small business competition. Organizational Dynamics, v. 46, n. 3, p. 171-181, 2017.

VARGO, S. L.; LUSCH, R. F. Evolving to a New Dominant Logic for Marketing. Journal of Marketing, v. 68, n. 1, p. 1-17, 2004.

VERHUN, A.; VERHUN, M. Strategic Management Analysis in the Eu Countries. Baltic Journal of Economic Studies, v. 3, n. 5, p. 52-60, 2017.

VRCHOTA, J. et al. Influence of strategic management in Czech SMEs and their growth rate. Business Trends, v. 6, n. Special Issue, p. 4-10, 2016.

WEBER, P.; GENESTE, L. A.; CONNELL, J. Small business growth: strategic goals and owner preparedness. Journal of Business Strategy, v. 36, n. 3, p. 30-36, 2015.

WIT, B. Strategy: An International Perspective. 6. ed. Winchester: Cengage Learning EMEA, 2017.

YANG, D.; JIANG, W.; ZHAO, W. Proactive environmental strategy, innovation capability, and stakeholder integration capability: A mediation analysis. Business Strategy and the Environment, n. January, p. 1-14, 2019.

ZARIFIAN, P. Objectif compétence. Paris: Liaisons, 1999. 